\author{
O. Nakonechna ${ }^{1}$, K. Ivanenko ${ }^{2}$, A. Kuryliuk ${ }^{1}$, N. Belyavina ${ }^{1}$
}

\title{
Parameters of Crystal and Electronic Structure and Magnetic Properties of Mechanically Alloyed $\mathrm{Ni}_{3} \mathrm{C}$ Cubic Carbide
}

\author{
${ }^{1}$ Taras Shevchenko national university of Kyiv, Kyiv, Ukraine, lesnak4@gmail.com \\ ${ }^{2}$ Institute of Macromolecular Chemistry NAS of Ukraine, Kyiv, Ukraine, spite02@gmail.ru
}

\begin{abstract}
The cubic $\mathrm{Ni}_{3.3} \mathrm{C}$ carbide has been fabricated by mechanical alloying of elemental $\mathrm{Ni}$ powder and the multiwalled carbon nanotubes in a high energy planetary ball mill. Crystal structure of carbide obtained belongs to the defective structure of $\mathrm{ZnS}$ sphalerite type according to x-ray diffraction data. Parameters of the electronic structure of $\mathrm{Ni}_{3.3} \mathrm{C}$ were calculated by linearized muffin-tin orbitals method within the plane-wave approximation using as an input the defined parameters of crystal structure. Magnetic properties, such as temperature and field dependences of the magnetic susceptibility of $\mathrm{Ni}_{3.3} \mathrm{C}$ have been studied. Based on experimental data obtained by studying the crystal structure and magnetic properties of $\mathrm{Ni}_{3.3} \mathrm{C}$, as well as on the basis of calculations of electronic structure parameters, a preferred displacement of the carbon atoms in tetrahedral voids of Ni crystal lattice has revealed.

Keywords: mechanical alloying; nanoscale material; x-ray diffraction; crystal structure; electronic structure; superparamagnetism.
\end{abstract}

Received 19 January 2021; Accepted 10 February 2021.

\section{Introduction}

Mechanical alloying has recently been gaining increasing application due to the possibility of obtaining novel nanoscale materials with an interesting set of functional properties. Previously we have successfully synthesized such well-known $d$-metal carbides as $\mathrm{TiC}$, $\mathrm{ZrC}, \mathrm{HfC}, \mathrm{VC}, \mathrm{NbC}, \mathrm{TaC}, \mathrm{Mo}_{2} \mathrm{C}, \mathrm{W}_{2} \mathrm{C}, \mathrm{WC}, \mathrm{Fe}_{3} \mathrm{C}$ and $\mathrm{Co}_{3} \mathrm{C}$ using multi-walled carbon nanotubes (CNTs) as a carbon component of the charge [1-5]. It was also shown that the crystal structures of the carbides obtained have certain features in the atoms arrangement [5]. At the same time the mechanically alloyed Ni-CNT (3:1) powder obtained significantly differs from the synthesis products obtained by other authors. We reported on fabrication of a novel cubic $f c c$ carbide $\mathrm{Ni}_{3} \mathrm{C}\left(\mathrm{NiC}_{0.33}\right)$ with a defective sphalerite $\mathrm{ZnS}$ type structure as a result of Ni-CNTs (3:1) charge processing [6], while V.K. Portnoi et al. [7] have synthesized the well-known metastable hexagonal $h p c \mathrm{Ni}_{3} \mathrm{C}$ carbide by mechanical alloying of Ni-graphite charge (3:1). Previously, J. Yang et al. [8] have predicted the existence of cubic carbide
$\mathrm{Ni}_{4} \mathrm{C}$ under certain conditions by the first-principles calculations based on density functional theory. However, our experimental data on the tetrahedral displacement of carbon atoms in the synthesized $f c c \mathrm{Ni}_{3} \mathrm{C}$ carbide [6] contradicts the theoretical model of cubic $\mathrm{Ni}_{4} \mathrm{C}$ carbide [8], in which carbon atoms demonstrate the octahedral displacement. However, it should be noted that both studies $[6,8]$ deal with the formation of a supersaturated solid solution on the base of $f c c$ nickel lattice.

Of particular interest is the magnetic state of nickel atoms in the mechanically alloyed $\mathrm{Ni}_{3} \mathrm{C}$ carbide $[9,10]$. L. Yue et al. [11] have shown that mechanically alloyed $\mathrm{Ni}_{3} \mathrm{C}$ is ferromagnetic, although the hysteresis loop is not saturated. $\mathrm{Ni}_{3} \mathrm{C}$ is predicted to be nonmagnetic in the ordered phase. Linearized muffin-tin orbitals (LMTO) calculations indicate that even small amounts of disorder bring the system close to satisfying the Stoner criterion $[12,13]$ via the formation of small, locally Ni-rich regions.

Hence, the aim of this research was to study the parameters of crystal and electronic structure and 
magnetic properties of the mechanically alloyed $\mathrm{Ni}_{3.3} \mathrm{C}$ carbide taking into account the indicated discrepancy in the inner circle of carbon atoms at the formation of cubic $\mathrm{NiC}_{x}$ carbide of variable composition.

\section{Experimental procedure}

\subsection{Materials studied}

Multiwalled carbon nanotubes used in this study were synthesized by the catalytic chemical vapor deposition method (CVD) at TM Spetzmash Ltd (Kyiv, Ukraine). The physical properties of the CNTs are as follows: the average diameter is $(10-20) \mathrm{nm}$, the specific surface area (determined by argon desorption method) is $(200-400) \mathrm{m}^{2} / \mathrm{g}$ and their bulk density varies from 20 to $40 \mathrm{~g} / \mathrm{dm}^{3}$.

Elemental $\mathrm{Ni}$ powder (99.9 wt.\% purity, particle sizes of $\sim 80 \mu \mathrm{m}$ ) and multiwall CNTs in the amount of 3:1 were mixed to give the desired average composition and sealed in a vial under an argon atmosphere. High energy planetary ball mill used for mechanical alloying is a custom made model developed at the Metal Physics and Ceramics Laboratory of Taras Shevchenko National university of Kyiv. Hardened stainless steel balls (15 units of $15 \mathrm{~mm}$ diameter) and a vial (70 $\mathrm{mm}$ height, $50 \mathrm{~mm}$ diameter) with a ball-to-powder weight ratio of 40:1 were used. The vial temperature was held at below $375 \mathrm{~K}$ during the experiments by air cooling. The milling process was cyclic with $5 \mathrm{~min}$ of treatment and $25 \mathrm{~min}$ of cooling time. The rotation speed was equal to $1480 \mathrm{rpm}$; the acceleration was about $50 \mathrm{~g}$ : the pressure for a substance particle reached $5 \mathrm{GPa}$. More details on the method of obtaining test samples could be found in Ref. [6].

\subsection{Experimental methods.}

Mechanically alloyed test samples were certified by the $\mathrm{x}$-ray phase analysis and structural analysis (with a complete refinement of the crystal structure and composition of the $\mathrm{NiC}_{\mathrm{x}}$ carbide formed). The detailed description of XRD methods used in this study are clearly presented at www.X-ray.univ.kiev.ua.

Magnetometric studies were carried out in the temperature range $300-900 \mathrm{~K}$ in the field of $550 \mathrm{kA} / \mathrm{m}$ under purified argon medium using the Faraday-type magnetometer with microbalance. The accuracy of the susceptibility measurements $\chi(T)$ was better than $1.5 \%$ and the temperature $\triangle T \leq 0.5 \mathrm{~K}$. Field-dependent measurements of magnetization were carried out using a vibrating sample magnetometer (vibration frequency $70 \mathrm{~Hz}$ ) at room temperature.

Parameters of electronic structure such as density of the electronic states (DOS) and energy at the Fermi level $\left(E_{\mathrm{F}}\right)$ were calculated using the MStudio MindLab 7.0 software package in the linearized muffin-tin orbitals within the plane-wave approximation (LMTO PLW) using the results of crystal structure determination of $\mathrm{Ni}_{3.3} \mathrm{C}$ synthesized cubic carbide as an input.

\section{Experimental results}

\subsection{X-ray diffraction study.}

XRD study has revealed that mechanical alloying of Ni-CNT (3:1) charge leads to a formation of the nickelbased solid solution $\left(\mathrm{NiC}_{x}\right.$ phase of variable composition), the lattice parameter of which gradually increases with the processing time increasing [6]. Structural calculations were performed to define the arrangement of carbon atoms in the crystal structure of the carbide formed. Two models were applied within the Fm3m space group (No. 225), namely, when Ni atoms are placed in position $4(a) 000$, and $\mathrm{C}$ atoms are placed either in the position $4(b) \frac{1}{2} 1 / 21 / 2$ or in $8(c) 1 / 4 \frac{1}{4} 1 / 4$. As a result, it was shown that the carbon atoms in the structure of formed carbide partially occupy positions $8(c)$ 1/4 $1 / 4 \quad 1 / 4$ (tetrahedral voids of $f c c$ nickel lattice) only, and do not occupy the positions $4(b) 1 / 21 / 21 / 2$ (octahedral voids) at the initial stage of the milling (up to $300 \mathrm{~min}$ ). However, according to XRD data, partial filling of the octahedral voids becomes possible when a certain part of tetrahedral voids is filled with carbon atoms.

The nature of the filling with carbon atoms of the tetrahedral and one of the octahedral voids demonstrates Fig. 1. Crystallographic data of the mechanical alloying products, for which the magnetic properties were studied, are listed in Table 1.
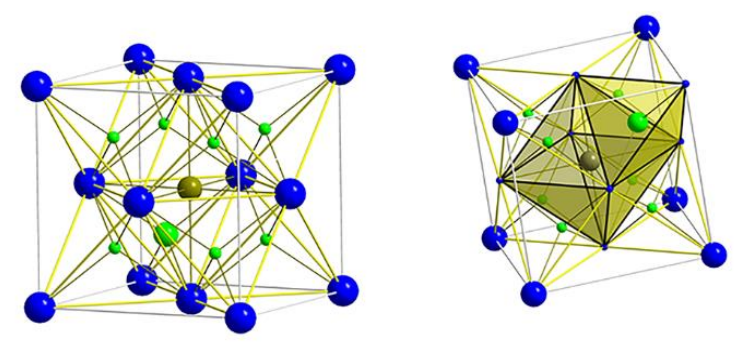

Fig. 1. Displacement of carbon atoms in the nickel crystal lattice (dark circles) and their coordination polyhedra: $\mathrm{C}$ atoms are marked as light green circles placed in tetrahedral voids. $\mathrm{C}$ atom is marked as swamp circle placed in the octahedral void. C atoms of larger radius are placed in the basic positions of $1 / 4$ $1 / 4 \frac{1}{4}$ Ta $1 / 21 / 21 / 2$.

Table 1

Crystallographic parameters of Ni powder and Ni-CNT $(3: 1)$ blend processed in a high energy ball mill

\begin{tabular}{|l|l|l|c|c|c|c|}
\hline \multirow{2}{*}{ Sample } & \multirow{2}{*}{$\begin{array}{c}\text { Synthesis } \\
\text { product }\end{array}$} & $\begin{array}{c}\text { Lattice } \\
\text { parameter } a \\
(\mathrm{~nm})\end{array}$ & $\begin{array}{c}\text { Total } \\
\text { content } / x\end{array}$ & $\begin{array}{c}\text { Tetra- } \\
\text { voids }\end{array}$ & $\begin{array}{c}\text { Octa- } \\
\text { voids. }\end{array}$ & $\begin{array}{c}\text { Coherent } \\
\text { scattering } \\
\text { block size } \\
\text { (nm) }\end{array}$ \\
\hline 1-Ni (350 min) & $\mathrm{Ni}$ & $0.3521(1)$ & - & - & - & 54 \\
\hline 2-Ni-CNT (210 min) & $\mathrm{Ni}_{4} \mathrm{C}$ & $0.3546(1)$ & $20.1 / 0.25$ & 20.1 & - & 12 \\
\hline 3-Ni-CNT (350 min) & $\mathrm{Ni}_{3.3} \mathrm{C}$ & $0.3549(1)$ & $23.4 / 0.31$ & 22.6 & 0.8 & 11 \\
\hline
\end{tabular}




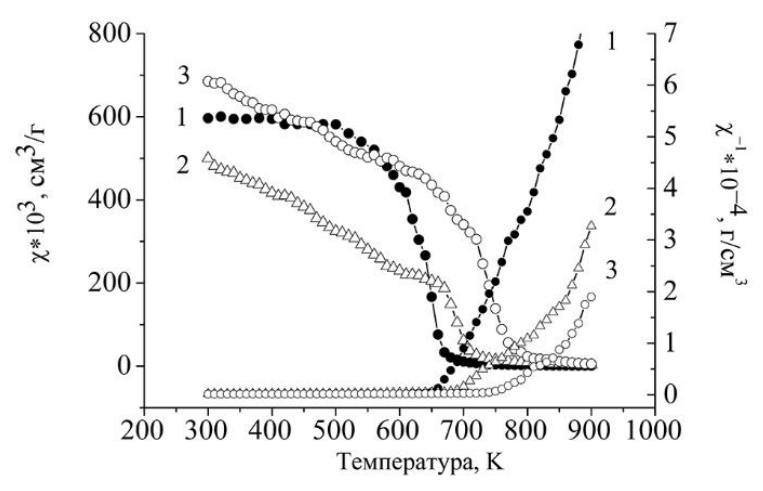

Fig. 2. $\chi(T)$ and $1 / \chi(T)$ dependences of $\mathrm{Ni}$ powder and synthesis products obtained at different milling time: 1 - Ni (350 min); 2 - Ni-CNT (210 min); 3 - Ni-CNT (350 min).

\subsection{Magnetometric study}

Experimental temperature dependencies of magnetic susceptibility $\chi(T)$ were found to be similar in general for all samples studied (Fig. 2). These magnetic polytherms demonstrate a two-stage behavior corresponding to different magnetic states. Herein, the initial stage of $\chi(T)$ dependencies (up to $650-750 \mathrm{~K}$ ) is characterized by a continuous and monotonic decrease and its meaning at room temperature $\chi_{300}$ is close to $\chi_{300}$ of the initial nickel powder milled $\left(\approx 6.0 \cdot 10^{5} \mathrm{~cm}^{3} / \mathrm{g}\right)$. At the same time, $\chi(T)$ character both for the milled nickel and for milled $\mathrm{Ni}$ CNT powders completely differs from that of bulk Ni in the ferromagnetic state, which is characterized by an abrupt decrease of $\chi$ in the vicinity of the Curie temperature $\left(T_{\mathrm{C}}=631 \mathrm{~K}\right)$ in this temperature range.

Test samples 1 and 3 selected after $350 \mathrm{~min}$ of mechanical alloying (Table 1) were also studied using a vibrating magnetometer. As a result, it has revealed that the nickel powder (sample 1) and milled Ni-CNT charge (sample 3) demonstrate similar dependencies of magnetization on the external magnetic field, that is, $M-H$ hysteresis loops (Fig. 3). Magnetic characteristics of the samples obtained from these curves are listed in Table 2.

At the second stage of the process (at temperatures above $650 \mathrm{~K}$ ) the magnetic susceptibility polytherms $\chi(T)$ of 1-3 samples are well described by the CurieWeiss law. A linear fitting of $1 / \chi(T)$ dependencies,
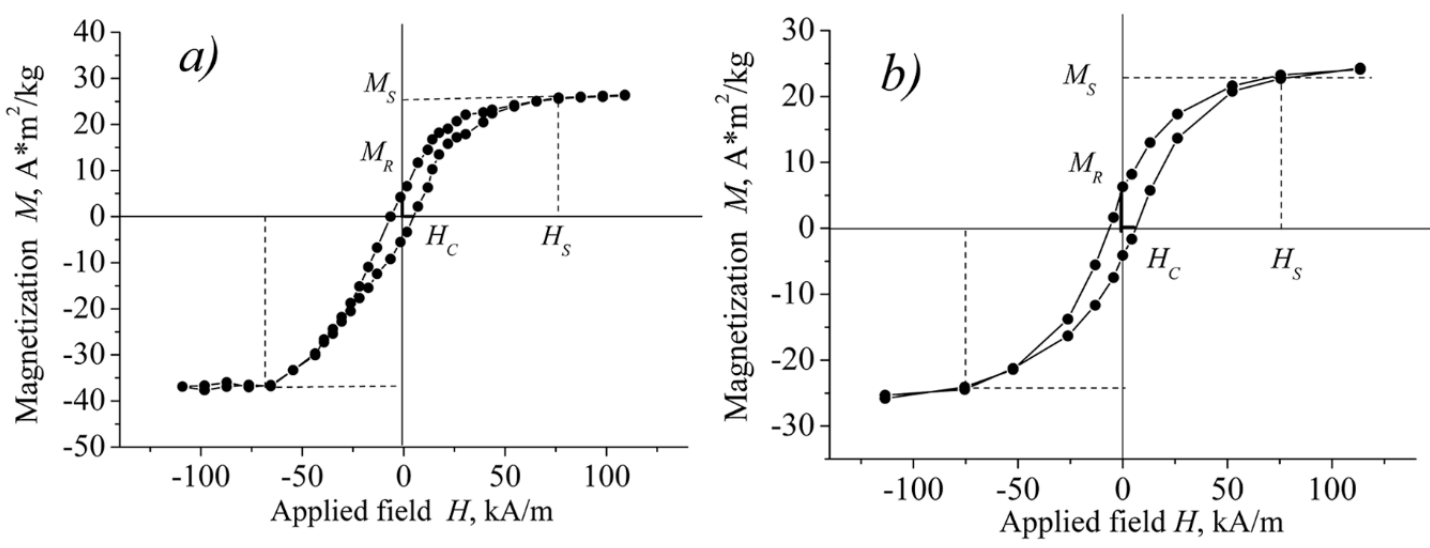

Fig. 3. $M-H$ dependences of Ni powder and sample 3-Ni-CNT milled for $350 \mathrm{~min}$.

Table 2

Magnetic characteristics of samples studied

\begin{tabular}{|c|c|c|c|c|c|c|c|c|}
\hline \multirow[b]{2}{*}{ Sample } & \multirow{2}{*}{$\begin{array}{l}\text { Coercive } \\
\text { force } H_{\mathrm{c}} \\
(\mathrm{kA} / \mathrm{m})\end{array}$} & \multirow{2}{*}{$\begin{array}{l}\text { Residual } \\
\text { magneti- } \\
\text { zation } M_{\mathrm{r}} \\
\left(\mathrm{A} \cdot \mathrm{m}^{2} / \mathrm{kg}\right)\end{array}$} & \multicolumn{2}{|c|}{$\begin{array}{l}\text { Saturation } \\
\text { magnetization }\end{array}$} & \multirow{2}{*}{$\begin{array}{l}\text { Magnetizing } \\
\text { field } \\
\text { strength } H_{\mathrm{S}} \\
(\mathrm{kA} / \mathrm{m})\end{array}$} & \multirow{2}{*}{$\begin{array}{l}\text { Magnetic } \\
\text { moment, } \\
\mu_{\mathrm{Ni}}\left(\mu_{\mathrm{B}}\right)\end{array}$} & \multirow{2}{*}{$\begin{array}{l}\text { Curie } \\
\text { tempera- } \\
\text { ture } T_{\mathrm{C}} \\
(\mathrm{K})\end{array}$} & \multirow{2}{*}{$\begin{array}{c}\text { Para- } \\
\text { magnetic } \\
\text { moment } \\
\mu_{\mathrm{Ni}}\left(\mu_{\mathrm{B}}\right)\end{array}$} \\
\hline & & & $\begin{array}{c}M_{\mathrm{S}} \\
\mathrm{A} \cdot \mathrm{m}^{2} / \mathrm{kg} \\
(\mathrm{emu} / \mathrm{g}) \\
\end{array}$ & $M_{\mathrm{S}}\left(\mu_{\mathrm{B})}\right.$ & & & & \\
\hline $\begin{array}{l}\mathrm{Ni}_{3} \mathrm{C} h p c 300 \mathrm{~K} \\
{[11]}\end{array}$ & 5.7 & - & 0.8 & 0.007 & - & 0.008 & - & - \\
\hline $\begin{array}{l}\text { Ni-bulk. } 300 \mathrm{~K} \\
{[9,13]}\end{array}$ & 1.5 & 3.0 & 57.6 & 0.564 & $76.0-$ & 0.606 & 631 & - \\
\hline $\begin{array}{l}\text { Ni-nanopowder. } \\
260 \text { K. } 45 \mathrm{~nm} \\
{[10]}\end{array}$ & 9.2 & 9.67 & 44.3 & 0.433 & - & 0.466 & 616 & - \\
\hline $1-\mathrm{Ni}(350 \mathrm{~min})$ & 2.2 & 3.0 & 37.6 & 0.368 & 76.5 & 0.395 & 630 & 1.73 \\
\hline $\begin{array}{l}\text { 2-Ni-CNT } \\
\min )\left(\mathrm{Ni}_{4.0} \mathrm{C}\right)\end{array}$ & - & - & - & - & - & - & 687 & 2.97 \\
\hline $\begin{array}{l}\text { 3-Ni-CNT } \\
\min )\left(\mathrm{Ni}_{3.3} \mathrm{C}\right)\end{array}$ & 5.7 & 6.6 & 23.1 & 0.226 & 76.9 & 0.243 & 745 & 3.18 \\
\hline
\end{tabular}


providing in this temperature range (Fig. 2), allows us to determine the paramagnetic Curie temperature $T_{\mathrm{C}}$ and the values of the paramagnetic moments per nickel atom $\mu_{\mathrm{Ni}}$ for each sample studied (Table 2). More details about these studies are presented in our work [14].

\subsection{Calculation of the parameters of electronic} structure

In order to obtain a more complete and thorough understanding of all the differences that carbon atoms introduce into the electronic structure of nickel in dependence on their localization (either in the tetrahedral or octahedral voids of $\mathrm{Ni}$ crystal lattice), we have performed calculations of the electronic band structure of $f c c$ nickel. Several models of displacement of a carbon atom either in the position $1 / 4 \frac{1}{4} \quad 1 / 4$ (model $\mathrm{Ni}_{4} \mathrm{C}$ (tetra.)) or in $1 / 2 \quad 1 / 2 \frac{1}{2}$ position (model $\mathrm{Ni}_{4} \mathrm{C}$ (octa.)) of Ni lattice have considered (Table 3). Herein, it is $\mathrm{Ni}_{4} \mathrm{C}$ model content that is the closest to the content of $\mathrm{Ni}_{3.3} \mathrm{C}$ carbide synthesized ( $\approx 23$ at.\% C, sample 3 (350 min)), which crystal structure and magnetic properties were studied experimentally (Tables 1,2). Calculations of the electronic structure were carried out using LMTO method taking into account the spin unrestricted option (spin-polarized density functional theory) for unpaired electrons.

The calculated density of electronic states (DOS, $N(E))$ for pure $f c c \mathrm{Ni}(a=6.654$ a.u. $)$ is presented at Fig. 4. The curve obtained completely coincides with reference data [13] and shows that the top of the $\mathrm{Ni}$

Table 3

Parameters of electronic structure calculated for $\mathrm{Ni}$ and cubic $\mathrm{Ni}_{4} \mathrm{C}$ carbides

\begin{tabular}{|c|c|c|c|c|c|c|}
\hline Model & $\begin{array}{c}\mathrm{Ni} \text { atom } \\
\text { displacement }\end{array}$ & $\begin{array}{c}\mathrm{C} \text { atom } \\
\text { displacement }\end{array}$ & $\begin{array}{c}\mathrm{C} \\
\text { content. } \\
\text { (at. \%) }\end{array}$ & $\begin{array}{c}\text { Fermi } \\
\text { energy } \\
E_{\mathrm{F}}(\mathrm{eV})\end{array}$ & $\begin{array}{c}\text { Saturation } \\
\text { magnetization } M_{\mathrm{S}} \\
\left(\mu_{\mathrm{B}}\right)\end{array}$ & $\begin{array}{c}\text { Magnetic } \\
\text { moment. } \\
\mu_{\mathrm{Ni}}\left(\mu_{\mathrm{B}}\right)\end{array}$ \\
\hline $\mathrm{Ni}_{4} \mathrm{C}$ octa. [8] & \multirow{4}{*}{$\begin{array}{llll}\text { Ni1 } & 0 & 0 & 0 \\
\text { Ni2 } & 1 / 2 & 1 / 2 & 0 \\
\text { Ni3 } & 1 / 2 & 0 & 1 / 2 \\
\text { Ni4 } & 0 & \frac{1}{2} & 1 / 2\end{array}$} & $1 / 21 / 21 / 2$ & 20 & - & $\begin{array}{c}0.06(\mathrm{Ni} 2-\mathrm{Ni} 4) \\
0.64(\mathrm{Ni} 1)\end{array}$ & $\begin{array}{c}2.45(\mathrm{Ni} 2-\mathrm{Ni} 4) \\
2.48(\mathrm{Ni} 1)\end{array}$ \\
\hline$f_{c c} \mathrm{Ni}$ & & - & 0 & 10.1961 & 0.560 & 0.691 \\
\hline $\mathrm{Ni}_{4} \mathrm{C}$ (tetra.) & & $1 / 41 / 41 / 4$ & 20 & 29.0917 & 0.0062 & 2.86 \\
\hline $\mathrm{Ni}_{4} \mathrm{C}$ (octa.) & & $1 / 21 / 21 / 2$ & 20 & 17.8398 & $\begin{array}{c}0.021(\mathrm{Ni} 2-\mathrm{Ni} 4) \\
0.006(\mathrm{Ni} 1)\end{array}$ & $\begin{array}{c}2.10(\mathrm{Ni} 2-\mathrm{Ni} 4) \\
1.36(\mathrm{Ni} 1) \\
\end{array}$ \\
\hline
\end{tabular}
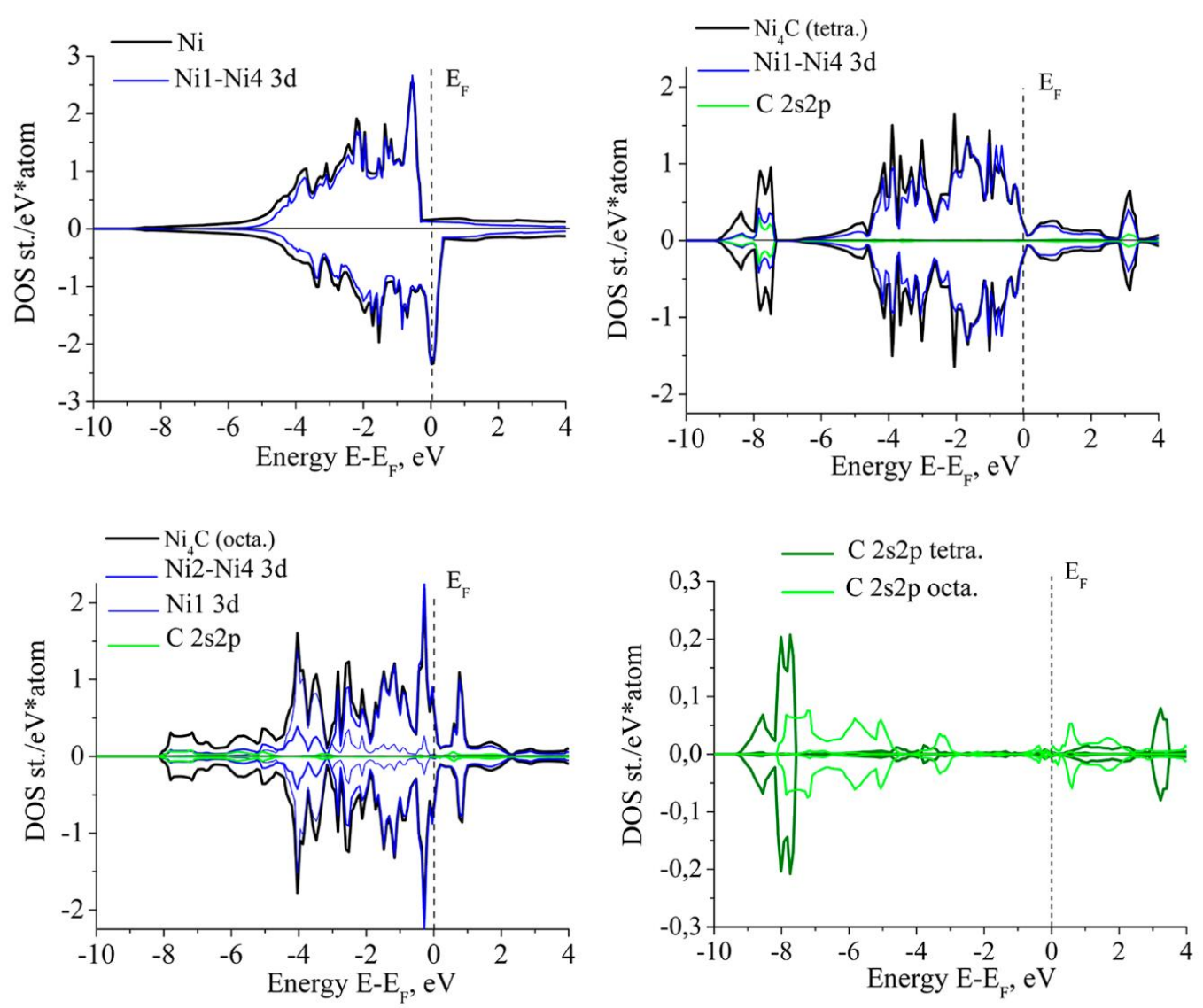

Fig. 4. Calculated DOS spectra of $\mathrm{Ni}, \mathrm{Ni}_{4} \mathrm{C}$ (tetra.) and $\mathrm{Ni}_{4} \mathrm{C}$ (octa.) calculated for the cubic carbide $\mathrm{Ni}_{3.3} \mathrm{C}$ synthesized. 
valence band is mainly formed by its $3 d$ state (blue lines). At the same time, $3 p$ and $3 s$ states of $\mathrm{Ni}$ are located at the bottom of the valence band and make almost no contribution to the total DOS (black lines) (Fig. 4).

DOS spectra were calculated for two cubic $\mathrm{Ni}_{4} \mathrm{C}$ (tetra.) and $\mathrm{Ni}_{4} \mathrm{C}$ (octa.) models, applying the same arrangement of the nickel atoms within a primitive $\mathrm{Ni}$ lattice ( $a=6.705$ a.u.), which imitates its $f c c$ lattice and different location of $\mathrm{C}$ atoms (Table 3, Fig. 4). It should be noted that in the case of the $\mathrm{Ni}_{4} \mathrm{C}$ (tetra.) model the carbon atom (position $1 / 41 / 41 / 4$ ) equally interacts with each of four basic nickel (Ni1, Ni2, Ni3 and Ni4) atoms, which are located on equal interatomic distances at the vertices of its tetrahedron. In this case, the interatomic distances of $\mathrm{CNi}_{4}$ polyhedron are equal to $0.1537 \mathrm{~nm}$ (Table 3). Whereas, in the case of the $\mathrm{Ni}_{4} \mathrm{C}$ (octa.) model, the $\mathrm{CNi}_{6}$ octahedron includes only $\mathrm{Ni} 2, \mathrm{Ni} 3$, and $\mathrm{Ni} 4$ atoms (interatomic distances of $0.1775 \mathrm{~nm}$ ) by pairs, while interatomic distances between four Nil and $\mathrm{C}$ atoms are much longer $(0.3074 \mathrm{~nm})$. Due to this fact, in the case of the $\mathrm{Ni}_{4} \mathrm{C}$ (octa.) model, $3 d$ band of $\mathrm{Ni}$ consists of two subbands with the contributions of $3 d$ electrons of Ni2-Ni4 atoms (dark blue line in Fig. 4) and $3 d$ electrons of the Ni1 atom (light blue line), in contrast to the single $3 d$ band of $\mathrm{Ni}$ atoms in the $\mathrm{Ni}_{4} \mathrm{C}$ (tetra.) model (dark blue line).

If, as shown above, the top of the valence band of the carbide $\mathrm{Ni}_{4} \mathrm{C}$ model is mainly formed by $3 d$ electrons of nickel atoms, then its bottom one is formed by a complex of $2 s$ and $2 p$ states of $\mathrm{C}$ as well as $4 p$ and $4 s$ states of $\mathrm{Ni}$ (Fig. 4). Moreover, in the $\mathrm{Ni}_{4} \mathrm{C}$ (tetra.) model, strong $s p^{2}$ hybridization of carbon states and $p d^{3}$ hybridization of nickel states leads to the formation of a separate energy level, while these states form only the bottom of the valence band (Fig. 4) in the $\mathrm{Ni}_{4} \mathrm{C}$ (octa.) model.

Fig. 5 presents the spin polarization spectra $p(\mathrm{E})$ for pure $\mathrm{Ni}, \mathrm{Ni}_{4} \mathrm{C}$ (tetra.) and $\mathrm{Ni}_{4} \mathrm{C}$ (octa.) models calculated as $p=(N \uparrow-N \downarrow) /(N \uparrow+N \downarrow)$.

While magnetic features of pure Ni correlate with the Stoner criterion of the ferromagnetic order [12], theoretical calculations show that $\mathrm{Ni}_{4} \mathrm{C}$ carbide should be either nonmagnetic $\left(\mathrm{Ni}_{4} \mathrm{C}\right.$ (tetra.)) or weakly magnetic $\left(\mathrm{Ni}_{4} \mathrm{C}\right.$ (octa.)) material. This phenomenon is additionally approved by the calculated saturation magnetization values $M_{S}$ listed in Table 3 .

Thus, the observed ferromagnetic behavior of the mechanically alloyed 3-Ni-CNT sample 3 (Fig. 3) does not correlate with theoretical predictions on the magnetism of $\mathrm{Ni}_{3.3} \mathrm{C}$ carbide. However, a possible explanation for the ferromagnetism of this sample (Fig. 3 , Table 2) consists in a presence of magnetic clusters of pure Ni in 350 min milled Ni-CNT charge. Besides, D.S. Il'yushchenkov et al. [16] have shown that Ni particles with a size of about $2.5 \mathrm{~nm}$ embedded in non-magnetic matrices can already exhibit ferromagnetic properties with partial magnetic moment $\mu_{\mathrm{Ni}}=0,6 \mu_{\mathrm{B}}$. Moreover, such particles will not be detected by XRD method due to their small size.

However, there are arguments in favor of the fact that carbon embedded in the nickel lattice through mechanical alloying should change the magnetic properties of the carbide synthesized significantly. First,

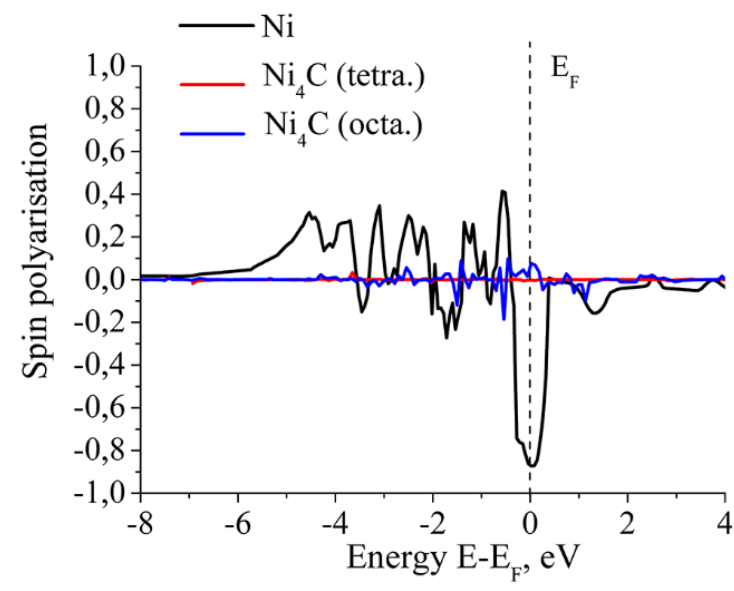

Fig. 5. Spin polarization spectra calculated for $f c c \mathrm{Ni}$ and two models of the cubic carbide $\mathrm{Ni}_{4} \mathrm{C}$.

the parameters of $\mathrm{M}-\mathrm{H}$ dependences (Fig. 3) are lower than those for pure Ni nanopowder (Table 2). Second, analysis of $\chi(T)$ dependence (Fig. 2) gives us a reason to apply the superparamagnetism formalism to explain the magnetic moment $\mu_{\mathrm{Ni}}$ value of $\mathrm{NiC}$ synthesized [12]. In other words, the magnetic state of the $3-\mathrm{Ni}-\mathrm{CNT}$ sample corresponds to that of a system of randomly oriented and non-interacting single-domain magnetic nanoparticles.

Thus, the ferromagnetic properties of the mechanically alloyed 3-Ni-CNT sample, which contains only cubic $\mathrm{Ni}_{3.3} \mathrm{C}$ carbide (according to XRD data), are completely caused by the presence of single-domain magnetic nanoparticles of pure $\mathrm{Ni}$.

Besides, it should be noted that just one electron with uncompensated spin moment $s=1 / 2$ makes a contribution to a total magnetic moment of mechanically alloyed $f c c$ $\mathrm{Ni}, \mu_{\mathrm{Ni}}=1.73 \mu_{\mathrm{B}}$ (Table 2). Since $\mathrm{C}$ atoms embed into $\mathrm{Ni}$ crystal lattice and fill mainly its tetrahedral voids at the formation of $\mathrm{Ni}_{4.0} \mathrm{C}$ and $\mathrm{Ni}_{3.3} \mathrm{C}$ carbides, they also destroy certain amount of $\mathrm{Ni}-\mathrm{Ni}$ bonds and increase the number of electrons with uncompensated spins, increasing the total magnetic moment up to $\mu_{\mathrm{Ni}} \approx 3.0 \mu_{\mathrm{B}}$ (Table 2 ). An increase in the number of valence electrons in the $\mathrm{Ni}_{4.0} \mathrm{C}$ carbide is also evidenced by a significant shift of the Fermi level, which occurs regardless of possible localization of $\mathrm{C}$ atoms in the initial nickel lattice (Table 3).

J. Yang et al. [8] and C.M. Fang et al [16] have speculated on the formation of cubic carbide on the basis of $f c c$ or $h p c$ Ni crystal lattices. Magnetic characteristics of the predicted carbide were estimated also. In addition, J. Yang et al. [8] placed C atoms in $1 / 21 / 2 \frac{1}{2}$ position, that is, assuming its location in the center of octahedral void when considering the DOS of cubic carbide $\mathrm{Ni}_{4} \mathrm{C}$. The arrangement of carbon atoms in the center of the tetrahedral void has not been considered yet.

A significant advantage of our research consists in the determination of the parameters of electronic structure of $f c c \mathrm{NiC}$ taking into consideration the results of XRD studies of the crystal structure of $\mathrm{Ni}_{3.3} \mathrm{C}$ cubic carbide synthesized, which convincingly indicate that the carbon atoms are located in the tetrahedral voids of the basic nickel lattice [6]. It is also known that such spatial 
orientation can be provided by $s p^{3}$ hybridization of $\mathrm{C}$ orbitals, which leads to the formation of four identical hybrid orbitals directed towards the vertices of the tetrahedron. In our opinion, it is the tetrahedral coordination of the carbon atom, that is more natural than the octahedral one, the implementation of which requires the transfer of carbon atoms to an excitation state to ensure $s p^{3} d^{2}$ hybridization. Moreover, hybridized $s p^{3}$ orbitals easily overlap with $3 d$ orbitals of $\mathrm{Ni}$ atoms, which leads to formation of new energy states in $\mathrm{Ni}_{4} \mathrm{C}$ (tetra.) model considered (Fig. 4).

\section{Conclusions}

This paper presents the results of an experimental study of crystal structure and magnetic properties of cubic $\mathrm{Ni}_{3.3} \mathrm{C}$ carbide obtained by mechanical alloying of Ni-CNT charge (3:1) in a high-energy planetary ball mill. Parameters of the crystal structure (defect $\mathrm{ZnS}$ sphalerite type) of carbide fabricated were used for its electronic structure calculation.

Inconsistencies in observed and predicted magnetic characteristics of carbide obtained is explained by the existence of single-domain magnetic nanoparticles in the samples. The nonmagnetic state could be provided when $\mathrm{Ni}$ crystal lattice is completely saturated with the carbon atoms. This scenario is realized with a prolongation of mechanical alloying of the charge.

A preferred display of the carbon atoms in tetrahedral voids of $\mathrm{Ni}$ crystal lattice has revealed based on experimental data on the crystal structure and magnetic properties of cubic $\mathrm{NiC}_{x}$ carbide of variable composition synthesized, as well as the parameters of its electronic structure.

\section{Funding}

The study was supported by the Ministry of Education and Science of Ukraine (grant No. 0119U100184).

Nakonechna O. - D. Sci., Senior Researcher, Physics Department;

Ivanenko K. - Ph.D., Senior Researcher;

Kuryliuk A. - Ph.D., Researcher, Physics Department;

Belyavina N. - Ph.D., Senior Researcher, Physics Department.

[1] M. Dashevskyi, N. Belyavina O. Nakonechna, Yu. Titov, French-Ukrainian Journal of Chemistry 7(1), 113 (2019) (DOI: 10.17721/fujcV7I1P113-120).

[2] O. Nakonechna, M. Dashevskyi, N. Belyavina, Metallofizika I NoveishieTekhnologii 40(5), 414 (2018) (DOI: 10.15407/mfint.40.05.0637).

[3] O. Boshko, O. Nakonechna, N. Belyavina, M. Dashevskyi, S. Revo, Advanced Powder Technology 28(3), 964 (2017) (DOI: 10.1016/j.apt.2016.12.026).

[4] O.I. Nakonechna, M.M. Dashevski, A.M. Kurylyuk, N.N. Bilyavyna, Physics and Chemistry of Solid States, 20(1), 13 (2019) (DOI: 10.15330/pcss.20.1.13-1713).

[5] O.I. Nakonechna, M.M. Dashevskyi, O.I. Boshko, V.V. Zavodyanny, N.N. Belyavina, Progress in Physics of Metals 20(1), 1 (2019) (DOI: 10.15407/ufm.20.01.001).

[6] O.I. Nakonechna, N.N. Belyavina, M.M. Dashevskyi, A.M. Kuryliuk, V.A. Makara, Dopov. Nac. akad. nauk Ukr. 4, 50 (2019) (DOI: 10.15407/dopovidi2019.04.050).

[7] V.K. Portnoi, A.V. Leonov, S.N. Mudretsova, S.A. Fedotov, The Physics of Metals and Metallography, 109(2), 153 (2010) (DOI: 10.1134/S0031918X10020079).

[8] J. Yang, Z. Xiao, Z. Li, Q. Wen, F. Yang, Computational Condensed Matter, 1, 51 (2014) (DOI: 10.1016/j.cocom.2014.11.002).

[9] L. He, W. Zheng, W. Zhou, H. Du, C. Chen, L. Guo, Journal of Physics: Condensed Matter. 19(3), 036216 (2007) (DOI: 10.1088/0953-8984/19/3/036216).

[10] X. He, W. Zhong, C. T. Au, Y. Du, Nanoscale Research Letters, 8(1), 446 (2013) (DOI: 10.1186/1556-276X8-446).

[11] L. Yue, R. Sabiryanov, E.M. Kirkpatrick, D.L. Leslie-Pelecky, Physical Review B 62(13), 8969 (2000) (DOI: 10.1103/PhysRevB.62.8969).

[12] R.M. Bozort, Ferromagnetism (IEEE Press, Wiley, 1993).

[13] J.F. Loffler, W. Wagner, Phys. Rev. B, 57(5), 2916 (1998) (DOI: 10.1103/PhysRevB.57.2915).

[14] O.I. Nakonechna, N.N. Belyavina, R.V. Ostapenko, A.M. Kuryliuk, V.A. Makara, Dopov. Nac. akad. nauk Ukr. 6, 36 (2019) (DOI: 10.15407/dopovidi2019.06.036).

[15] D.S. Il'yushchenkov, V.M. Kozhevin, S.A. Gurevich, Phys. Solid State, 61, 1683 (2019) (DOI: 10.1134/S1063783419100184).

[16] C.M. Fang, M.H. F.Sluiter, M.A. Van Huis, H.W. Zandbergen, Physical Review B 86(13), 134114 (2012) (DOI: 10.1103/PhysRevB.86.134114). 


\section{О.І. Наконечна ${ }^{1}$, К.О. Іваненко ${ }^{2}$, А.М. Курилюк ${ }^{1}$, Н.М. Білявина ${ }^{1}$ \\ Кристалічна, електронна структура та магнітні властивості кубічного карбіду $\mathrm{Ni}_{3,3} \mathrm{C}$}

${ }^{1}$ Фізичний факультет, Київський національний університет імені Тараса Шевченка, Київ, Україна, lesnak4@gmail.com
${ }^{2}$ Інститут хімії високомолекулярних сполук НАН України, Київ, Украӥна, spite02@ gтаil.ru

В роботі викладені результати дослідження продукту синтезу, який було отримано механохімічною обробкою у високоенергетичному планетарному млині шихти порошку $\mathrm{Ni}$ та багатостінних вуглецевих нанотрубок (BНT) у співвідношенні 3:1 (Ni:BHT). Показано, що за даними рентгенівського аналізу вказаний продукт синтезу є кубічним карбідом $\mathrm{Ni}_{3.3} \mathrm{C}$, кристалічна структура якого належить до дефектної структури типу $\mathrm{ZnS}$ сфалерит. Досліджено температурну та польову залежності магнітної сприйнятливості цього продукту синтезу. Використовуючи результати визначення кристалічної структури, методом лінеаризованих мафін-тін орбіталей у наближенні плоских хвиль були розраховані спектри електронної густини та інші параметри електронної структури синтезованого кубічного карбіду $\mathrm{Ni}$..3 . На основі експериментальних даних, отриманих при дослідженні кристалічної структури та магнітних характеристик одержаного матеріалу, а також на основі розрахунків параметрів електронної структури показано, що в кубічному карбіді змінного складу $\mathrm{NiCx}$, який утворюється при механохімічній обробці шихти Ni-BHT, розташування атомів вуглецю в тетраедричних порах $\epsilon$ пріоритетним.

Ключові слова: механічне легування; нанорозмірний матеріал; рентгенівська дифракція; кристалічна структура; електронна структура; суперпарамагнетизм. 